\title{
WhatsApp dan Konsep Jarak Sosial Baru Di Masyarakat
}

\author{
Afina Amna \\ Pascasarjana UIN Sunan Kalijaga \\ finaamna@gmail.com
}

\begin{abstract}
Abstrak. Whatsapp (WA) sebagai media sosial baru merubah komunikasi masyarakat di dunia maya. Komunikasi yang awalnya hanya bisa dilakukan di dunia nyata, berkembang dengan adanya dunia maya yang menjadikan komunikasi bisa dilakukan tanpa harus bertemu, dan bisa dilakukan secara cepat dan bisa dirasakan seakan nyata. Untuk itu, penelitian ini bertujuan untuk mengetahui Bagaimana komunikasi masyarakat sebelum ada WA dan setelah ada WA? Apakah WA merubah konsep jarak sosial bagi masyarakat? Penelitian ini penting dilakuan agar kita mengetahui bagaimana WA sebagai media komunikasi yang aktif dan masif digunakan oleh masyarakat dapat merubah konsep jarak sosial baru di masyarakat. Metode yang digunakan adalah kualitatif dengan pengambilan data melalui wawancara terhadap beberapa orang pengguna WA. Wawancara ini dilakukan dengan metode random sampling dengan pemilihan informan secara acak. Teori yang digunakan dalam penelitian ini adalah teori jarak sosial. Penelitian ini menemukan bahwa WA merubah komunikasi di dunia maya dan WA juga merubah konsep jarak sosial baru karena setelah grup WA masif digunakan, orang-orang bebas menyebarkan informasi dan berhak untuk mengomentari tanpa takut pada jarak sosial di dunia nyata. Orang-orang juga bisa lebih mudah mewujudkan simpatinya karena grup di WA memudahkan mereka untuk melakukan informasi dan koordinasi untuk dapat melakukan aktivitas yang menujukkan simpati pada orang lain.
\end{abstract}

\section{Kata kunci: Komunikasi, Whatsapp, Jarak Sosial}

Abstract. Whatsapp (WA) as a new social media changes people's communication in cyberspace. Communication that initially can only be done in the real world, develops with the existence of cyberspace that makes communication can be done without having to meet, and can be done quickly and can be felt as if real. For this reason, this study aims to find out how public communication is before there is WA and after there is WA? Does WA change the concept of social distance for society? This research is important to do so that we know how WA as an active and massive communication media used by the community can change the concept of new social distance in society. The method used is qualitative data collection through interviews with several WA users. This interview was conducted by random sampling method with the selection of informants randomly. The theory used in this study is the theory of social distance. This study found that WA changed communication in cyberspace and WA also changed the concept of new social distance because after massive WA groups were used, people were free to disseminate information and had the right to comment without fear of social distance in the real world. People can also more easily realize their sympathies because 
groups in WA make it easier for them to carry out information and coordination to be able to carry out activities that show sympathy for others.

\section{Keywords: Communication, Whatsapp, Social Distance}

\section{Pendahuluan}

Komunikasi pada hakekatnya adalah utama yang digunkan manusia untuk bisa hidup, sampai saat ini. Komunikasi adalah cara agar kita saling mengerti dan saling memahami apa yng diinginkan oleh rang lain dan begitupun sebaliknya. Pada awalnya sebelum mengenal bahasa komunikasi manusia berupa suara teriakan yang digunakan untuk saling memanggil dan saling mengenali, setelah itu berkembang dengan adanya alat, sehingga komunikasi menggunakan medi seperti kentungan, bedug atau hal-hal yang bisa didengar oleh banyak orang, setelah itu muncullah bahasa ehingga orang bisa berkomunikasi dengan menggunakan bahasa. Komunikasi dengan bahasa ini dilakukan dengan cara verbal dan digunakan oleh hampir semua orang diseluruh dunia dan dilakukan dalam waktu yang cukup lama dibandingkan dengan fase sebelumnya (Bungin, 2009). Namun begitu komunikasi berkembang lagi dengan adanya jaringan internet yang dapat menghubungkan orang di seluruh dunia. Adanya internet ini memunculkan media baru dan memunculkan berbagai media sosial baru salah satunya whatsapp (WA).

Media sosial (medsos) sendiri diartikan sebagai sarana yang digunakan oleh orang-orang untuk berinteraksi satu sama lain dengan cara menciptakan, berbagi, serta bertukar informasi dan gagasan dalam sebuah jaringan dan komunitas virtual. Media sosial juga bisa diartikan sebagai alat yang memungkinkan penggunanya mempresentasikan dirinya maupun berinteraksi, bekerja sama, berbagi, berkomunikasi dengan pengguna lain dan membentuk ikatan secara virtual (Nasrullah, 2016). Di Indonesia, media sosial baru-baru ini menjadi penting sejak diluncurkannya smartphone atau telepon pintar yang memungkinkan orang untuk mengakses apapun dengan satu kali sentuhan.

Sebelum smartphone beredar luas, orang berhubungan dengan menggunakan telephone duduk untuk bisa berkomunikasi dengan cara bercakap-cakap. Setelah itu muncullah Hand Phone (HP) yang membawa perubahan baru, karena memungkinkan orang untuk bisa berkomunikasi tidak hanya dengan suara saja, namun bisa dengan tulisan dengan cara mengirim pesan pendek atau sering disebut SMS (Short Massage Send). Inovasi teknologi dan media sosialpun tak hanya berhenti disitu. Sejak internet menjadi konsumsi masyarakat luas, muncullah Facebook (FB) sebagai media sosial baru yang memungkinkan orang untuk bisa mengunggah foto, membuat status, menyebar berita bahkan memuat curhat di media FB. Kemunculan FB membuat perubahan besar dalam media sosial dan berpengaruh terhadap perubahan komunikasi di masyarakat (Juju \& Sulianta, 2010). Komunikasi jarak jauh yang hanya terbatas pada percakapan dan pengiriman pesan pendek berubah menjadi kebutuhan sehari-hari sejak FB menjadi konsumsi utama di masyarakat. FB menjadi medsos yang 
sangat penting dimiliki untuk mengunggah berbagai gambar sebagai pengakuan diri atau sebagai media untuk melihat aktivitas orang lain tanpa diketahui.

FB pun menjadi salah satu inspirasi yang memunculkan medsos baru yang lebih beragam dan lebih inovatif. Maka muncullah medsos baru seperti twitter, line, Instagram (IG) Whatsapp (WA), dan medsos lain yang juga memungkinkan orang untuk terhubung dengan jaringan dunia maya yang luas. Keberadaan FB yang menjadi medsos utama pun mulai tergeser karena berkembangnya smartphone yang memugkinkan masyarakat untuk mengakses medsos lain secara mudah dan cepat. Namun begitu, menurut data hootsuite per April 2017 FB, masih menduduki peringkat pertama pengguna terbanyak dan diikuti oleh Youtube, WA dan Instagram.

WA saat ini mempunyai tempat tersendiri di masyarakat. Medsos yang baru ada sejak 2009 ini pada tahun 2015 mulai dikenal luas oleh masyarakat Indonesia. Masyarakat mulai beralih dari HP ke smartphone dan beralih dari SMS ke WA. Salah satu nilai lebih dari WA adalah WA memungkinkan kita untuk bisa berhubungan dengan banyak orang dan tidak hanya antar satu orang dengan satu orang, karena WA memungkinkan kita untuk membentuk grup secara virtual yang dapat memudahkan kita untuk mengirim satu kabar untuk semua orang dalam satu grup (Jumiatmoko, 2016). WA juga memiliki fitur yang berbeda dengan media sosial lain, yaitu terdapat voice note/pesan suara yang memungkinkan orang untuk mengirimkan pesan tanpa harus mengetik, tapi cukup dengan suara. Fitur dan aplikasi WA yang inovatif menjadikan pengguna WA tidak hanya terbatas pada kaum muda saja, saat ini WA digunakan sebagai media informasi untuk semua usia. Hubungan komunikasi yang dulunya penuh pertimbanganpun saat ini menjadi lebih santai dan ringan. Hal ini memunculkan konsep baru tentang jarak sosial yang ada di masyarakat.

Beberapa penelitian tentang jarak sosial hanya berfokus pada jarak sosial pada di dunia nyata. Seperti dalam penelitian yang dilakukan Resti Amanda yang berjudul Hubungan Antara Prasangka Masyarakat Terhadap Muslimah Bercadar Dengan Jarak Sosial. Penelitian ini menitikberatkan pada prasangka masyarakat terhadap wanita bercadar yang menimbulkan jarak sosial antara masyarakat dengan wanita yang bercadar (Resti, 2017). Penelitian lain yaitu tentang Pengaruh Jarak Sosial dan Hirarki Pada Tindak Tutur Permintaan dan Perintah Suap Dalam Pemberitaan Kasus Suap Oc Kaligis Oleh Kompas.com. penelitian ini dilakukan oleh Prihantoro yang berfokus pada jarak sosial antara penutur dan mitra tutur (Prihantoro, 2015). Perbedaan penelitian yang terdahulu dengan yang dilakukan penulis adalah ranah penelitian penulis yang berfokus pada jarak sosial di dunia maya.

Penulis lebih berfokus meneliti tentang jarak sosial di dunia maya, karena sejak medsos menjadi alat komunikasi utama di masyarakat. Saat ini hampir semua mahasiswa menggunakan WA sebagai media utama dalam arus informasi. Mereka menggunakan WA untuk mendapat/mencari informasi dari tempat yang jauh, agar mereka bisa memantau berita/informasi tersebut secara lebih dekat. Namun disisi lain, saat mereka bersama teman-teman mereka dan berkumpul bersama, mereka lebih tertarik dengan untuk mencari informasi dari orang/tempat yang jauh atau tempat yang dekat. Hal ini menjadikan WA memunculkan konsep baru dalam jarak sosial. Jarak sosial biasanya selalu dilekatkan karena adanya perbedaan ras, suku dan etnis dimasyarakat nyata, mempunyai arti lain saat didunia maya. 
Untuk itu timbul pertanyaan baru Bagaimana komunikasi masyarakat sebelum ada WA dan setelah ada WA? Apakah WA merubah konsep jarak sosial bagi masyarakat? Oleh sebab itu, peneliti ingin menguraikan secara lebih mendalam bagaimana konsep jarak sosial di dunia maya khususnya di media sosial WA.

\section{Metode Penelitian}

Penelitian ini menggunakan metode penelitian kualitatif dengan pengumpulan data yang dilakukan peneliti yaitu dengan wawancara. Wawancara yang dilakukan peneliti adalah wawancara mendalam yang dilakukan secara langsung dan dilakukan face to face atau tatap muka. Pemilihan informan ini dilakukan dengan metode random sampling denngan mewaancarai informan secara acak. Informan dipilih berdasarkan kelayakan dan ketersediaan akses peneliti terhadap narasumber dan kompetensi mereka, bukan atas representativeness (keterwakilan) (Syahputra, 2017). Metode seperti ini dilakukan agar penulis tahu lebih mendalam tentang apa yang penulis teliti dari informan yang diwawancarai (West dan Turner, 2008.

Wawancara seperti itu dilakukan dilakukan karena penelitian ini tidak dimaksudkan untuk memperoleh external validity, melainkan lebih bertujuan untuk memperoleh pemahaman mengenai suatu realitas dalam konteksnya yang spesifik. Seluruh informan adalah mahasiswa pengguna aktif WA. Penulis mewawancarai beberapa orang yang menggunakan WA, dan dampak penggunaan WA bagi kehidupan sehari-hari mereka. Namun, dalam penelitian ini penulis hanya menuliskan tiga informan yang penulis anggap sebagai jawaban keterwakilan dari beberapa informan.

Dalam kaitannya dengan ilmu sosial fenomena ini bisa diteliti dengan menggunakan teori jarak sosial. Jarak sosial pertama kali dicetuskan oleh Bogardus yang mengukur jarak sosial dengan skala yang dibuatnya yang saat ini dikenal dengan nama skala Bogardus (Liliweri, 2005). Jarak sosial menurut Henslin diartikan sebagai kadar untuk mengukur kedekatan atau penerimaan yang kita rasakan terhadap kelompok lain (Henslin, 2006). Selain itu penulis juga menggunakan teori alienasi Karl Marx untuk menganalisis fenomena ini.. Teori yang dicetuskan Marx berfokus pada keterasingan para pekerja yang dibagi dalam empat kelompok. Pertama para pekerja yang teralienasi dari tindakan bekerja. Kedua, pekerja yang teralienasi dari hasil pekerjaannya. Ketiga, pekerja yang teralienasi dengan pekerja lain. Keempat, pekerja yang teralienasi dari potensi kemanusiaannya. Penulis disini akan menggunakan konsep alienasi yang dikaitkan dengan komunikasi saat ini, dimana pekerja (manusia) teralienasi dengan manusia lain (Upe, 2010).

\section{Pembahasan}

\section{WhatsApp (WA) sebagai Media Komunikasi Baru}

Komunikasi pada dasarnya adalah kebutuhan manusia sejak manusia ada, bahkan sejak manusia belum mengenal peradaban dan adat istiadat, manusia telah saling membutuhkan dan hal itu bisa tercapai dengan cara berkomunikasi. Komunikasi yang berawal dari teriakan, berkembang ke non verbal, simbol dan pada akhirnya sampai pada komunikasi yang kita gunakan sehari-hari (Bungin, 2009). Semakin berkembangnya dunia dan banyaknya perubahan yang ada, komunikasi manusia pun juga mengalami perkembangan. Sejak dimulainya revolusi industri, manusia yang awalnya hidup berkelompok, mulai berpencar, berpisah dan 
bertransmigrasi menjadikan manusia membutuhkan media komunikasi yang mempunyai daya jangkau yang luas. Ini memicu para ilmuan untuk menciptakan alat komunikasi baru untuk memudahkan komunikasi manusia.

Media menurut Menurut Michel Foucault seorang filsuf Prancis menyatakan bahwa media membuat pengetahuan menjadi mungkin dalam momen sejarah tertentu. Sedangkan Marshall McLuhan adalah sebuah pesan tersendiri. Media pada hakekatnya adalah alat, sehingga media komunikasi adalah alat untuk berkomunikasi, yang saat ini bisa digolongan kedalam dua kelompok. Pertama, hot media diartikan sebagai high definition yaitu media yang visualisasinya lebih nyata sehingga partisipasi konsumen rendah. Sedangkan cool media diartikan sebagai low definition yaitu media yang visualisainya kurang nyata sehingga menjadikan konsumen menjadi lebih aktif. Sedangkan WA digolongkan dalam media baru dimana visualisasinya tinggi namun penggunanya tetap aktif dalam berpartisipasi di media tersebut.

Media baru menjadi kajian yang menarik untuk dikaji karena kedatangannya menghadirkan kajian-kajian yang lebih segar dan membuat banyak perubahan dalam masyarakat. Sejak kemunculannya, WA menjadi salah satu media baru untuk komunikasi yang memungkinkan kita berkomunikasi seperti di dunia nyata. Beberapa komunikasi yang bisa dilakukan via WA yaitu: Pertama, chatting, adalah komunikasi yang dilakukan dengan cara mengirim pesan lewat tulisan. Kedua, voice note, adalah suatu pesan suara yaitu bentuk komunikasi yang dilakukan dengan cara merekam suara untuk dikirimkan. Ketiga, calling atau panggilan adalah komunikasi dengan cara bercakap-cakap seperti dalam saluran telephone. Keempat video call adalah komunikasi yang memungkinkan kita untuk melihat lawan bicara secara langsung. Terakhir adalah status. Status WA adalah salah satu vitur WA yang memungkinkan pengguna WA membuat status (tulisan, gambar, suara atau video) dan memungkinkan orang untuk mengomentari status tersebut. Status di WA tidak bersifat permanen karena hanya bisa dilihat selama 1×24 jam.

Menurut beberapa informan motif mereka menggunakan WA sebagai media komunikasi utama adala karena berkembangnya tren di masyarakat. Ada informan yang sebelum menggunakan WA dia menggunakan Short Massage Sent (SMS) sebagai media komunikasi utama, namun dia sering ketinggalan informasi, seperti yang dipaparan di bawah ini:

"pas awal ada WA aaku gak begitu peduli soalnya masih banyak temen-temen yang menggunakan SMS, tapi setelah banyak temenku pakai, aku akhirnya juga ikut-ikutan pakai WA."

Hal tersebut banyak terjadi pada saat peralihan dari SMS ke WA. Beberapa cara komunikasi di WA memudahkan orang untuk mengekspresikan apa yang mereka rasakan dalam komunikasi lewat media sosial. WA pun memiliki beberapa vitur yang membuat komunikasi bisa terasa lebih interaktif. Saat masyarakat masih menggunakan SMS, untuk menujukkan ekspresi ditunjukkan dengan berbagai simbol, seperti :) untuk menujukkan ekspresi tersenyum :D untuk tersenyum besar :( untuk ekspresi sedih, T.T untuk ekspresi sedih dan simbol-simbol lain yang dibuat dengan abjad dan tanda baca. Selain menggunakan simbol mereka juga menggunakan katakata untuk menujukkan ekspresi mereka saat berkomunikasi. Kata "hahaha" sebegai ekspresi tertawa atau "wkwkwk" sebagai ekspresi tertawa becanda, dan "hiks hiks" sebagai ekspresi sedih, namun kata-kata tersebut dalam komunikasi virtual kurang 
bisa mewakili apa yang sebenarnya ingin diungkapkan dan menimbulkan banyak penafsiran.

Inovasi pun dilakukan untuk memudahkan masyarakat saling terhubung dengan komunikasi yang lebih interaktif, maka muncullah emoji dalam media sosial. Emoji merupakan emot yang digambarkan dengan bentuk kepala yang memiliki ekspresi yang bermacam-macam. Sedih, senang tertawa digambarkan secara unik dan lucu.

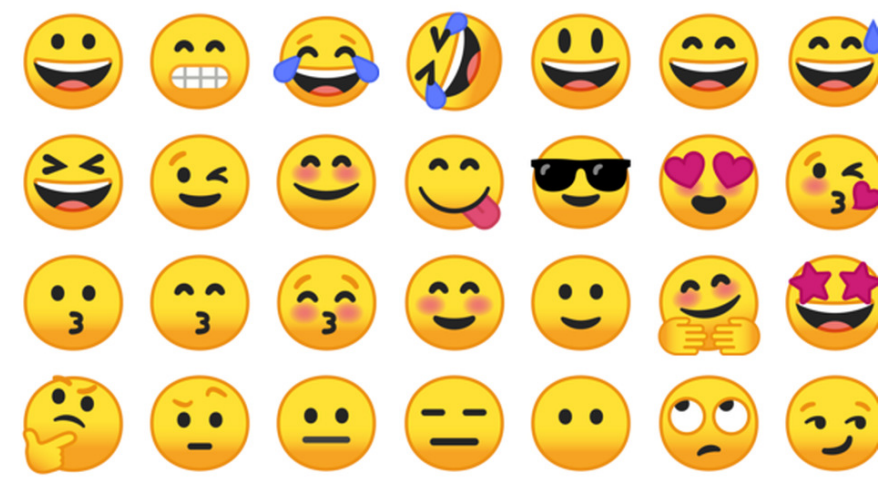

Gambar1 Gambar emoji di WA

Gambar emoji diatas adalah beberapa ekspresi yang ada di WA untuk menggambarkan bagaimana ekspresi kita saat berkomunikasi lewat WA. Emoji ini lebih dapat menujukkan dan dapat mewakili ekspresi apa yang ingin kita berikan atau yang baru kita alami saat berkomunikasi dengan lawan kita. Adanya emoji ini membuat perubahan yang cukup signifikan dalam komunikasi lewat media sosial. Komunikasi yang awalnya bersifat kaku dan terasa kering, menjadi lebih fleksibel, ceria dan lebih segar. Kemudahan dan banyaknya vitur yang ditampilkan WA menjadikan penggunaan WA meningkat begitu cepat dibandingkan dengan media sosial lain.

Selain itu banyak orang yang merasa lebih nyaman melakukan di WA dikarenakan orang yang kita ajak bicara tidak mengetahui secara nyata bagaimana keadaan kita saat membalas percakapan dengan lawan bicara kita. Selain itu kita bisa berfikir dua kali sebelum mengirimkan apa balasan kita. Berbeda dengan SMS yang biayanya dihitung berdasarkan satu kali kirim, percakapan di WA tidak dihitung satu kali kirim, sehingga banyak orang yang melakukan percakapan di WA tidak langsung satukalimat, namun hanya perkata bahkan hanya balas membalas emoji. Balas membals emoji ini menjadi semacam keasikan tersendiri bagi orang-orang khususnya remaja pengguna WA. Ini terjadi karena orang akan berfikir akan dibalas emoji apa jika lawan bicaranya mengirimkan emoji tertentu. Sehingga saat ini emoji tidak hanya sebuah simbol, tapi juga mempunyai makna tertentu dalam komunikasi dengan media baru.

Salah satu penyebabnya yaitu karena setelah WA menjadi konsumsi umum di masyarakat. Sejak WA diluncurkan dan smartphone beredar luas jarang sekali orang yang berkomunikasi dengan SMS ataupun HP. Sehingga orang yang belum memakai WA secara otomatis harus mengikuti arus untuk memakai WA jika tidak ingin menjadi orang terakhir yang mendapat informasi terbaru. 
Menurut informan 1, saat teman-temannya sudah memakai WA dan dia belum menggunakan WA, dia sering sekali tidak tahu informasi kuliah, karena informasi pergantian jadwal kuliah tidak lagi diumumkan satu persatu lewat SMS, namun diumumkan hanya di grup. Dia menyatakan pada awalnya dia tidak memakai WA karena dia masih bisa berkomunikasi dengan SMS dan Telephone, sehingga dia memutuskan untuk bertahan hanya dengan HP. Namun pada akhirnya, dia memutuskan untuk mengganti HP dengan smartphone, karena dia berkali kali tidak mendapat informasi tentang tugas kuliah atau pergantian jadwal kuliah. "aku ganti HP, karena sekarang orang jarang menyebarkan informasi lewat SMS dan aku merasa ketinggalan informasi, maka akhirnya aku beli smartphone baru dan memasang WA" Ini menujukkan bahwa banyaknya orang yang memakai WA membuat orang yang tidak memakai WA mau tak mau harus ikut menggunakan WA agar tidak ketinggalan informasi.

Selain bisa menyebarkan informasi secara mudah dan cepat, WA juga merubah konsumsi orang terhadap media sosial lain. Beberapa informan yang ditemui penulis menyatakan bahwa dengan WA mereka dapat mengubah mengirimkan apapun tanpa harus membuka media lain. Sebelum ada WA orang yang ingin mengirimkan file harus membuka email untuk mengirim dokumen, namun sekarang kita sangat dimudahkan dengan adanya WA karena kita bisa mengirim apapun dengan satu media tanpa harus membuka media lain. Bahkan kita bisa mengirimkan foto, dari kegiatan yang sedang kita lakukan saat itu juga kepada banyak orang, tanpa harus membuka media lain.

\section{Perubahan konsep baru tentang jarak sosial akibat WA}

Whatsapp (WA) sebagai media sosial baru telah merubah banyak hal dalam bidang komunikasi di dunia maya. WA sebagai media sosial yang banyak digunakan orang memungkinkan penggunanya untuk membuat grup virtual dengan beranggotakan orang-orang yang juga menggunakan aplikasi WA. Grup virtual ini tak terbatas jumlahnya, karena semua orang berhak dan bisa membuat, memasukkan, keluar dan menghapus grup WA mereka. Grup WA pun menciptakan konsep tentang jarak sosial baru. Jarak sosial mendeskripsikan jarak antara berbagai kelompok dalam masyarakat dan bukan merupakan jarak (lokasi). Gagasan ini tidak hanya mencakup perbedaan-perbedaan seperti kelas sosial, ras/etnis, gender atau seksualitas, tetapi juga fakta bahwa anggota kelompok yang berbeda kurang berbaur dibandingkan dengan anggota dari kelompok yang sama (Liliweri, 2005).

Komunitas virtual adalah kumpulan pengguna yang memiliki kesamaan dan terbentuk melalui ruang siber serta relasi yang terjadi di antara mereka termediasi secara elektronik. Di komunikasi virtual tidak ada kekuatan politik atau ekonomi dalam pengertian mikro yang memberikan dorongan kepada individu untuk menjadi bagian dari komunitas virtual tersebut (Nasrullah, 2016). Di komunitas virtual, khususnya WA grup biasanya dibentuk untuk menghimpun orang yang satu instansi, satu ikatan kekeluargaan, satu ikatan pertemanan atau ikatan lain yang memiliki tujuan yang sama.

Orang yang membuat WA akan menjadi admin grup di WA tersebut, dia bisa menambahkan anggota baru, mengeluarkan anggota ataupun menghapus grup tersebut. Orang yang tergabung dalam anggota WA juga berhak untuk menjadi anggota aktif dengan merespon berita dengan cepat, atau menjadi anggota pasif yang hanya membaca informasi tanpa berkomentar. Anggota di grup virtual ini juga berhak 
untuk keluar dari grup. Ini biasa terjadi karena keanggotaan ini bersifat virtual dan tak ada aturan yang mengikat di grup tersebut.

Pembuatan grup di WA mempunyai tujuan untuk berbagi komentar, tulisan, gambar, video, suara, dan dokumen. Selain itu WA bertuujuan untuk menyebarluasakan pengumuman maupun mempublikasikan karya dalam grup dalam satu kali pengiriman (Jumiatmoko, 2016). Ini memungkinkan kita mendapat informasi saat itu juga. Sejak kemunculan WA dan begitu mudahnya membuat grup WA, komunikasi pun mengalami perubahan. Perubahan komunikasi yang paling mendasar dari adanya grup WA ini adalah cepatnya informasi tersebar dari satu grup ke grup yang lain.

Beberapa orang yang menerima sutu informasi baru di WA biasanya langsung menyebarkan ke grup lain tanpa tahu apakah informasi itu benar atau hanya informasi bohong (hoaks). Walupun begitu grup WA juga menjadikan hubungan atau komunikasi yang jarang terjalin menjadi dapat erat kembali.

Menurut informan 1, dengan adanya grup wa, keluarganya yang tidak pernah berhubungan bisa dekat kembali karena seringnya berinteraksi di grup WA. Jarangnya berhubungan dikarenakan karena jauhnya jarak geografis di anggota keluarganya. Komunikasi yang dilakukan di grup pun tidak hanya sekedar basa-basi menanyakan kabar, namun juga berbagi informasi gambar dan bercanda di grup.

"keluargaku kan kebanyakan di jawa Timur, Bapak Ibuk di Magelang dan aku di Jogja, dulunya aku jarang banget ngubungin saudara, soalnya dulu kalo ngubungin tuh pasti baru ada apa-apa yang biasanya itu berita buruk, lha pas ada wa kita kan buat grup keluarga, jadinya sanagt sering interaksi, soalnya kan gak sungkan juga wong orang banyak, kalau grupnya lagi sepi biasanya ada yang mulai nyapa, terus biasanya berakhir dengan olok-olokan hahahah...."

Informasi tersebut menujukkan bahwa adanya grup WA dapat menjadikan hubungan keluarga yang jauh letaknya secara geografis dapat menjadi mudah. Keluarga yang awalnya hanya berkomunikasi jika ada hal penting berubah menjadi komunikasi yang sifatnya saling peduli atau komunikasi yang dilandasi oleh rasa saling memiliki. Hubungan ini menjadikan jarak sosial di keluarga besarpun melebur, karena setiap anggota keluarga yang tergabung dalam grup tersebut berhak untuk memulai percakapan dan berhak untuk berkomentar.

Informan 2 juga mengatakan semenjak ada WA hubungan komunikasi yang awalnya kaku terasa lebih fleksibel dan lebih mudah. Dia menuturkan bahwa:

"aku kan sudah alumni, terus ada grup alumni yang isinya anak-anak alumni dan ustad/ustadah, dan pak ustadku tuh ada yang sering banget kalau komen ngasih emoticon, aku rasanya gak bisa bayangin gimana Pak Ustad ku kalau nagis, soalnya emoticonnya nangis. Jadi kalau dulu gak pernah berhubungan dengan ustad/ustadah sekarang sering banget, awalnya dulu masih sungkan, tapi sekarang jadi biasa "

Penuturan diatas menujukkan adanya perubahan komunikasi antara murid dengan ustad/ustadah (guru). Di dunia nyata hubungan murid dan guru biasanya berlangsung cukup kaku, bahasa yang digunakan dalam komunikasi biasanya menggunakan bahasa formal dan dalam berkomunikasipun sangat memperhatikan 
tata krama. Komunikasipun jarang dilakukan sejak mereka menjadi alumni dan jarang bertemu lagi dengan guru-guru mereka. Ini berubah sejak muncul grup WA dan dibuatnya grup yang berisikan murid dengan guru. Komunikasi antara guru dan muridpun berubah menjadi lebih interaktif dan fleksibel, jarak sosial antara murid dan gurupun mengabur dalam grup ini.

Informan 3 mengatakan bahwa WA diarasa sangat bermanfaat saat dihubungkan dengan komunikasi. Salah satu hal yang paling dia rasakan dari penggunaan grup WA adalah saat ibu dari temannya meninggal. Dia mengatakan sejak di Jogja sering sekali dia tidak bisa ikut berkumpul atau mendatangi rumah duka, karena telatnya mendapat informasi atau karena sulitnya mengkoordinasi untuk bisa berkumpul secaraa bersama. Berbeda saat dia dan teman-temannya membuat grup baru di WA. Saat Ibu teman mereka meninggal informasi dapat langsung tersebar ke anggota grup dan beberapa jam kemudian mereka bisa berkumpul bersama untuk mendatangi rumah duka. Hal ini bisa dilakukan karena mudahnya mengkoordinasi kapan, dimana mereka akan berkumpul dengan memberikan instruksi yang disebar di WA.

Ini menujukkan adanya perubahan jarak sosial secara virtual, dimana dalam pembagian kelompok jarak sosial ini termasuk dalam jarak sosial afektif. Jarak sosial afektif adalah salah satu pendekatanjarak sosial yang berfokus pada afektivitas. Menurut pendekatan ini, jarak sosial berkaitan dengan afektivitas jarak, yaitu seberapa bersimpati anggota sebuah kelompok terhadap kelompok lain (Sumadiria, 2014). Simpati yang ditujukan disini yaitu adanya koordinasi yang dapat dilakukan dengan menggunakan media WA. Beberapa informan menyatakan bahwa beberapa grup WA yang miliki adalah grup yang beranggotakan teman-teman jauh yang sama-sama merantau dan jarang bertemu. Grup WA membuat mereka bisa mengetahui apa-apa yang teman-teman mereka lakukan, karena selain mendapat informasi di grup mereka juga bisa memantau dari story yang teman-teman mereka buat.

\section{Analisis Perubahan Konsep Jarak Sosial dengan Teori Alienasi Karl Marx}

Dari pembahasan yang telah dipaparkan diatas, fenomena yang terjadi tersebut juga bisa dianalisis dengan teori Karl Marx. Marx berasusmsi bahwa dalam dunia kerja, para pekerja teralienasi atau terasing dengan pekerja lain. Jika hal ini dilihat dari sudut pandang komunikasi, adanya WA membuat orang terasing dengan manusia lain. Pada masa lalu, manusia hanya hidup dalam satu dunia saja yaitu dalam dunia nyata. Saat itu orang yang bertemu orang akan melihatnya secara utuh dan melakukan pembicaraan secara sungguh-sungguh. Orang-orang yang berkumpul benar-benar akan memusatkan perhatian pada apa yang baru diduskusikan. Apa-apa yang dihadapan mereka adalah nyata dan tidak ada dunia lain yang menyainginya.

Semua berubah setelah muncul media sosial khususnya WA. Manusia saat ini telah memiliki dua dunia dalam kehidupannya yaitu dunia nyata dan dunia maya. Di dunia nyata seseorang bisa saja memiliki sifat yang pendiam dan tertutup, namun saat di dunia maya dia bisa menjadi orang yang begitu terbuka dan sangat ramah. Dunia maya yang dihadapi saat inipun dianggap lebih menarik dari dunia nyata yang menjadi tempat hidup. Perubahan ini dikarenakan banyak orang yang lebih berani berbicara secara tidak langsung daripada berbicara secara langsung.

Di dunia maya manusia dapat melihat aktifitas orang lain atau hal-hal yang tidak mereka ketahui. Orang-orang saat ini seperti tidak bisa lepas dari media sosial. 
Dalam suatu perkumpulan orang-orang saat ini tidak akan fokus $100 \%$ terhadap diskusi yang dihadapi. Manusia sekarang selalu mengecek HP nya beberapa kali walaupun itu dalam forum diskusi. Intensitas pertemuan yang harusnya bisa berjalan hangat dan intensif saat ini mulai berubah. WA merubah konsep jarak sosial baru yang menjadikan yang dekat menjadi jauh dan yang jauh menjadi dekat. Inilah yang dimaksud dengan adanya keterasingan manusia dengan manusia lain. Orang yang seharusnya mampu membangun ikatan sosial dalam komunitas yang nyata, saat ini menjadi terpisah dan diperparah dengan adanya hubungan sosial yang semakin kompetitif, sehingga kesempatan membangun komunikasi yang intensif menjadi sangat kecil.

\section{Kesimpulan}

Whatsapp sebagai media sosial baru saat ini banyak digunakan untuk oleh masyarakat, khususnya mahasiswa. WA telah membuat perubahan yang cukup besar dalam hubungan komunikasi mahasiswa di dunia maya. Perubahan tersebut antara lain:

1. Komunikasi yang awalnya hanya sebatas pada pesan teks pendek atau percakapan kini telah bertransformasi menjadi komunikasi yang lebih interaktif dengan menggunakan pesan teks, pesan suara, gambar, dan panggilan vidio.

2. Komunikasi jarak jauh yang awalnya kaku berubah menjadi lebih fleksibel karena adanya emooticon pada WA yang dapat menggambarakn ekspresi kita.

WA juga mengubah konsep jarak sosial baru dikarenakan:

1. Setelah grup WA masif digunakan orang-orang bebas menyebarkan informasi dan berhak untuk mengomentari tanpa takut pada jarak sosial di dunia nyata.

2. Orang-orang bisa lebih mudah mewujudkan simpatinya sejak terbentuknya grup WA, karena grup di WA memudahkan mereka untuk melakukan informasi dan koordinasi dengan cepat dan mudah untuk dapat melakukan aktivitas yang menujukkan simpati pada orang lain.

3. WA menjadikan manusia terasing dengan manusia lain yang mendekatkan yang jauh dan menjauhkan yang dekat.

\section{Saran}

Fenomena jarak sosial di dunia maya ini sebenarnya sangatlah beragam, di penelitian ini penulis hanya memaparkan sekelumit tentang jarak sosial di media sosial berupa Whatsapp (WA). Penelitian ini masih sangat dangkal dan masih perlu kritik, saran dan pengembangan agar penelitian ini bisa menyumbang di bidang akademik, khususnya di bidang ilmu komunikasi dan informatika. Penulis berharap semoga ada penelitian lain yang menyempurnakan penelitian ini ataupun menguak hal lain tentang jarak sosial di dunia maya.

\section{Referensi}

Amanda, R. (2017). Hubungan Antara Prasangka Masyarakat Terhadap Muslimah Bercadar Dengan Jarak Sosial. Jurnal RAP, 5(1), 72-81. 
Bungin, B. (2009). Sosiologi komunikasi. Prenada Media Group.

Henslin, J. M. (2006). Sosiologi dengan pendekatan membumi. Jakarta: Erlangga.

Juju, D., \& Sulianta, F. (2010). Hitam Putih Facebook. Elex Media Komputindo.

Jumiatmoko, M. (2016). WHATSAPP MESSENGER DALAM TINJAUAN MANFAAT DAN ADAB. Wahana Akademika: Jurnal Studi Islam dan Sosial, 3(1), 51-66.

Liliweri, A. (2005). Prasangka dan Konflik; Komunikasi Lintas Budaya Masyarakat Multikultur. LKIS PELANGI AKSARA.

Nasrullah, R. (2015). Media Sosial: Perspektif Komunikasi, Budaya, dan Sosioteknologi. Bandung: Simbiosa Rekatama Media.

Prihantoro, P. (2015). PENGARUH JARAK SOSIAL DAN HIRARKI PADA TINDAK TUTUR PERMINTAAN DAN PERINTAH SUAP DALAM PEMBERITAAN KASUS SUAP OC KALIGIS OLEH KOMPAS. COM. PROSIDING PRASASTI, 233-239.

Sumadiria, H. (2014). Sosiologi Komunikasi Massa. Simbiosa Rekatama Media, Bandung.

Syahputra, I. (2017). Demokrasi virtual dan perang siber di media sosial: Perspektif Netizen Indonesia. Jurnal ASPIKOM-Jurnal Ilmu Komunikasi, 3(3), 457-475.

Upe, A. (2010). Tradisi aliran dalam sosiologi: dari filosofi positivistik ke post positivistik. Rajawali Pers.

West, R., \& Turner, L. H. (2008). Pengantar teori Komunikasi: Analisis 156 dan Aplikasi, Buku 1 edisi ke-3, Terjemahan Maria Natalia Damayanti Maer. Jakarta: Salemba Humanika.

Winarso, H. P. (2005). Sosiologi komunikasi massa. Jakarta: Prestasi Pustaka. 